\title{
Lexical Gaps in Translation of Qur'anic Allusions in Hafez's Poetry: Strategies and Difficulties
}

\author{
Masoumeh Rahimkhani \\ Department of English, East Azarbaijan Science and Research Branch, Islamic Azad University, Tabriz, Iran \\ Bahloul Salmani \\ Department of English, East Azarbaijan Science and Research Branch, Islamic Azad University, Tabriz, Iran
}

\begin{abstract}
Translating culture-bound elements in literary translations seems to be one of the most challenging tasks to be performed by a translator. Taking this into account, this paper discusses the treatment of Qur'anic allusions in translation of Hafez's Divan from Persian into English. For this purpose a number of instances have been collected and the strategies applied by various translators have been identified. All these examples are highly-specific cultural references or words that are commonly known in Persian culture, but are generally unknown for the target culture reader. The examination of such items has been carried out through the English translations of Clark (2005) and Ordoubadian (2006) based on Venuti's overall strategies of domesticating and foreignizing. At the same time, the model of this research has been developed by using some of the translation strategies proposed by Leppihalme (1997). It was revealed that various strategies adopted by Ordoubadian (2006) are generally toward domesticating a term and by Clarke (2005) towards preserving its local color and cultural strangeness. Therefore, as demonstrated in this paper, the allusive language of the original poems and connotations conveyed by them were largely ignored by the translator.
\end{abstract}

Index Terms — culture-bound elements, allusion, literary translation, Hafez, strategies

\section{INTRODUCTION}

Translation has typically been used to transfer written or spoken source language (SL) texts to equivalent written or spoken target language (TL) texts (Darwish, 2010, p. 21; House, p. 31, 1997; Brislin, 1976, p. 1; Nida \& Taber, 1974, p. 12).

In current studies, the purpose of translation goes beyond the mere transference of words and forms, and cultural aspects of this activity gain more importance. Literary translation, when expected to take place between cultures, encounters the most troublesome role. In other words, the most challenging aspect of translation sets in when it comes to the transference of cultural elements (Hassan, 2011, p. 2).

Snell-Hornby (1988, p. 42) states, “The translation problem doesn't depend on the source text itself, but on the significance of the translated text for its readers as members of a certain culture with their constellation of knowledge, judgment and perception they have developed from it".

Considering the constraints of translating cultural words and notions, fields abundant with such items tend to be the most difficult to deal with. One of those demanding fields with its highly culture-bound nature is poetry.

Translation of poetry has always been controversial in the field of translation studies. There have been always numerous ideas concerning the possibility of poetry translation. For Connolly $(1998$, p. 170) "The translation of poetry is generally held to be the most difficult, demanding and possibly rewarding form of translation. It has been the subject of great deal of discussion". According to Mohaghegh (2011, p. 76), "Translation of poetry as a yet unanalyzed "black box' (Francis, 2006), has been a much debated issue since olden times, with many pros and cons and dichotomist reasoning as to its possibility or impossibility." It was Jakobson (2004, p. 143) who claimed, "Poetry by definition is untranslatable". Others, like Nabokov (2004, p. 127) would disagree: "I want translations with copious footnotes, footnotes reaching up to the top of this or that page so as to leave only the gleam of one textual line between commentary and eternity."

This is generally true for translation of all kinds of poetry, and the translation of Hafez (1324-1391) in particular. Fifty years of poetic writing by the fourteen-century Persian classical poet Hafez resulted in the complication of his Divan.

"Hafez is by universal consent the supreme master of the art of the Persian ghazal-a literary form generally equated with the lyric" (Arberry, 1974, p.1). As a student, Hafez evidently learned the Qur'an by heart (here his name is in Farsi, and here's how that ties out to his way of having learned the Qur'an), and his poetry proves that..." (Arberry, 1974, p. 3). Eslaminejad (1996, p. 5) is among those who acknowledge that Hafez is the one whose poetry is influenced by Qur'an. Consequently, many researchers have investigated this aspect of his poems that confirms the difficulty of their translation. 
Arberry (1974, p. 19) asserts, "Hafez employed elegant artifices as talmih (allusion) in his poems." Following the same line, Ordoubadian (2006, p. 11) asserts, "Hafez's verse gives a panoramic insight into the culture of Persia. Hafez's verse is a multifaceted gem that reflected different shades of light according to reader's state of mind." One "cannot take a dictionary in one hand and the Divan in the other to match words in Persian with those in English" (p. 16).

Regarding difficulties in translating Hafez's poetry, many researchers declare that such cultural barriers result from the lack of understanding in English language communities of Islamic principles and concepts, the meanings and metaphors connoted by the poetry, and the multifaceted language of Hafez. The words of his poem surpass their textual denotations; they take new shades of meaning dictated by the poetic context. So the translator must understand not only the basic elements of a poem such as rhyme, meter, and figurative language, but also the allusions that bear connotations and are culture dependent.

Consequently, the difference between SL culture and TL culture makes the process of translating a challenge. According to Darwish (2010, p. 244), "A lexical gap in translation occurs when there are cultural gaps between languages."

The present study examines the treatment of those allusions which reveal highly-specific cultural references or words that are commonly known in Persian culture, but are generally unknown for the target culture reader, casting light on both the frequency of the occurrences of different strategies applied for their translation and on the effect of background knowledge on the translators' performance.

\section{LITERATURE REVIEW}

\section{A. What Is Culture?}

Culture is defined in the Oxford Advanced Learner's Dictionary (2004, p. 306) as "the customs and beliefs, art, way of life and social organization of a particular country or group." Oswalt (1970, p. 15) provides a similar definition stating that it is "the life way of a population."

In Taylor's famous definition, "culture is that complex whole which includes knowledge, belief, art, morals, law, custom, and any other capabilities and habits acquired by man as a member of society" (Asad, 2009, p. 9).

In 1984, Larson defined culture as "a complex of beliefs, attitudes, values, and rules which a group of people share" (p. 431). He noted that the translator needs to understand beliefs, attitudes, values, and the rules of the SL audience in order to adequately understand the ST and adequately translate it for people who have a different set of beliefs, attitudes, values, and rules.

\section{B. Culture-bound Elements}

A translator using a cultural approach is simply recognizing that each language contains elements that are derived from its culture, that every text is anchored in a specific culture, and that conventions of text production and reception vary from culture to culture. Awareness of such issues can at times make it more appropriate to think of translation as a process which occurs between cultures rather than simply between languages. Most "cultural words", according to Newmark, are easy to detect since they are associated with a particular language and cannot be literally translated. However, many cultural customs are described in ordinary language, where literal translation would distort the meaning and thus the translation "may include an appropriate descriptive-functional equivalent" (Newmark, 1988, p. 95).

Some elements are difficult for the target text reader to understand. These elements are called "cultural words". According to Harvey (2003, p. 2) "culture-bound terms refer to concepts, institutions and personnel which are specific to the SL culture." Therefore, various strategies are used to reformulate them in other cultures.

According to Ordudari (2007, p. 1) "translating culture-bound elements in general and allusions in particular seem to be one of the most challenging tasks to be performed by a translator"; in other words, allusions are potential problems of the translation because of their connotations and implications in the source language (SL).

\section{Allusion}

According to Leppihalme (1997, p. 3), this is "the translation problem caused by small stretches of other texts embedded in the text at hand, which interact with and color it, but may be meaningless or puzzling in translation. Some such embedded texts or 'in-texts' (Nord, 1991, p. 102) are known as allusions."

Appearing abundantly in literary translations, allusions, as Albakry (2004, p. 3) pointed out, "are part of the prior cultural knowledge taken for granted by the author writing for a predominantly SL audience. To give the closest approximation of the source language, therefore, it was necessary to opt for glossing or using explanatory footnotes." However, elsewhere he claimed, "Footnotes ... can be rather intrusive, and therefore, their uses were minimized as much as possible" (p. 4).

According to Lass, "allusion is a figure of speech through which some counterparts are compared on the basis of their aspects to history, mythology, literature, religious books, etc.” (as cited in Leppihalm, 1997, p. 57).

Naturally translating from one language into another is difficult, but when accompanied by some allusions, the translator faces an even more difficult task. He or she must deal with allusions and references which are intermingled with diverse Qur'anic, historical, and cultural concepts (Albakry, 2004, p. 4). 


\section{Why Allusions Are Used?}

A whole range of factors, including social class, gender, education, personal reading history, situational and cultural context are no doubt involved in an individual sender's choosing to communicate via allusion. A sender must judge each communicative situation subjectively to decide whether an allusion is the optimal strategy for achieving the desired effect in that situation (Wilss, 1983, p. 58, as cited in Leppihalme, 1997, p. 31).

Allusion within a text is like puzzle and those who could solve it are going to feel affinity with the writer and feel the gap existed in the text (Leppihalme, 1997, p. 33).

As a result, "the main function of the allusion is to challenge the reader to solve the puzzle. More generally, allusions become puzzles when they cross a cultural divide." In general, "it may be said that allusions are used because of the extra effect or meaning they bring to the text by their associations or connotations" (Leppihalme, 1997, p. 34).

\section{E. Lexical Gap}

According to Darwish (2010, p. 244), a lexical gap occurs in translation

I. When the source language expresses a concept with a lexical unit where the target language expresses the same concept with a free combination of words, or with phrases.

II. The concept doesn't exist in the target language. (For example, "single parent".)

III. The source language denotation of the concept is different from the target language denotation of the same concept. (For example abstract concepts such as "democracy".)

IV. Where the source language and target language taxonomies are not congruent. For example, one language conflates and the other inflates by further dissection or slicing of the same concept into similar concepts that intersect. English has two separate yet intersecting concepts "engine" and "motor," while standard Arabic has only one concept "muharrik: محرك" that subsumes both of them.

$\mathrm{V}$. Where there is a cultural gap.

According to Cvilikaite (2006, p. 127) "Lexical gaps are instances of lack of lexicalization detected in a language while comparing two languages or in a target language during translation."

\section{F. Translation Procedures and Strategies}

Jakobson (1959) argued that "different languages resort to different techniques and strategies to cover deficiencies in the target language" (as cited in Miremadi, 2005, pp. 125-6).

Lörscher (1991, p. 76) defined the notion of strategy as "a potentially conscious procedure for the solution of a problem which an individual is faced with when translating a text segment from one language to another."

Translation strategies are the means that the translator, within the confines of his or her existing knowledge, considers best in order to reach the goals set by the translation task (Jääskeläinen, 1999, p. 111, as cited in Leppihalme, 1997, p. 27).

\section{G. Leppihalme's Strategies of Translation}

A distinction has been made between proper-name (PN) allusions and key-phrase (KP) allusions by Leppihalme (1997, p. 78-89). So the strategies for these two groups are somewhat different.

The translation strategies for PNs are basically:

- To keep the name unaltered

- To change it

- To omit it

These strategies have the following variations:

A. Retention of name with three subcategories:

(1a) use the name as such;

(1b) use the name, adding some guidance;

(1c) use the name, adding a detailed explanation, for example a footnote.

B. Replacement of a name by another with two subcategories:

(2a) replace the name with another SL name;

(2b) replace the name with a TL name;

C. Omission of the name; with two subcategories:

(3a) omit the name but transfer the sense by other means, for example by a common noun;

(3b) omit the name and the allusion altogether.

But the list of strategies for translation of KP allusions cannot be identical with PN strategies, though the general approach is similar. A retentive strategy with regard to KPs can mean a standard translation or minimum change. (Leppihalme, 1997, pp. 83-4)

Therefore, the potential strategies for KP allusions are as follows:

A. Use of a standard translation;

B. Minimum change, that is, a literal translation;

C. Extra-allusive guidance added in the text;

D. The use of footnotes, endnotes, and explicit explanations not supplied in the text; 
E. The addition of intra-allusive allusion-signaling features that depart from the style of the context, thus signaling the presence of borrowed words;

F. Replacement by a preformed TL item;

G. Reduction of the allusion to sense by rephrasal, in other words, making its meaning overt;

$\mathrm{H}$. Recreation, using a fusion of techniques;

I. Omission of the allusion.

\section{Methodology}

The present study is of comparative-descriptive approaches, of a qualitative nature, and includes a survey. Its aim is to analyze particular strategies applied to cope with allusions (Qur'anic ones) and to find which strategies are more frequent. Such allusions in Hafez's Divan and their equivalents in English translations by Clarke (2005) and Ordoubadian (2006) are identified.

After categorizing allusions, we can see the extent to which they had been correctly translated into the target language. The focus of this paper is to explore the notion of domestic and foreign strategies of translators to examine the translation practice in the case of Hafez's poetry, and then to explore whether or not the translators tend to retain culture-specific items in their translations. Indeed, the researcher has attempted to find a convincing answer to the following question: What are the most frequently used translation strategies in dealing with culture-specific items in the process of translating Qur'anic allusions in Hafez's ghazals? Moreover, what is the influence of the translator's background knowledge?

\section{ANALYSIS}

Here we will provide a small number of examples, taken from Hafez's Divan to illustrate the translation of culturespecific items within the descriptive framework of the study more operationally. The following examples will be discussed, mainly on the basis of Leppihalme's categories.

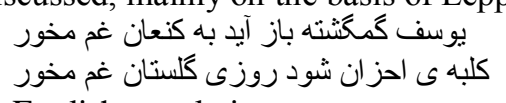

English translation:

1. Back to Kinan, lost Yusuf cometh: suffer not grief:

One day, the sorrowful cell becometh the rose-garden: suffer not grief (Clarke, 2005, p. 260).

2. Do not grieve: Joseph, lost, he returns to Canaan;

the hut of sorrow turns to a rose garden, do not grieve (Ordoubadian, 2006).

Hafez alluded to Yusuf and his well-known story in this couplet. The story of Joseph is almost known for everyone, as a result of this, in the first translation the translator retained the allusion based on Leppihalme's strategies, but here some lexical and orthographical changes are needed, as Yusuf should be changed to Joseph to remove obscurity. So the strategy applied here was retention without any guidance, and as a whole the translator was retaining something of the foreignness of the original. Besides them, two other terms, 'kinan' and 'the sorrowful cell', are also related to this story, 'Kinan' refers to the city where his father and family were living and 'the sorrowful cell' refers to a shack where Ya'qub spent hours crying and mourning at his lost son (Khorramshahi, 2001, p. 828). These are left in obscurity for the reader and need extra explanation and notes.

In the second translation, the translator replaced them by TL equivalents as 'Joseph' and 'Canaan'. Furthermore, the translator described through a footnote that here "the referent is to Jacob, the father of Joseph, whose name has been used by Hafez in a number of his ghazals. Of course through the ghazal he alludes to the separation of the father from his son for many decades and the hardships of Joseph in Egypt. This story in the Qur'an is much more elaborated than in the Old Testament and the sentiment of separation is more profoundly felt."

$$
\begin{aligned}
& \text { آسمان بار امانت نتو اذست كثيد }
\end{aligned}
$$

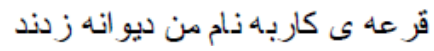

English translation:

The load of deposit (of love and of divine knowledge), the (lofty) sky could not endure:

In the name of helpless me, the dice of the work, they cast (Clarke, 2005, p. 189).

This couplet refers to the story of human creation, where Allah offers the load of deposit of love and obedience and worship to the Heavens and the Earth, but they refused except man, because of his foolishness (Khorramshahi, 2001, p. 678).

This couplet implicitly alluded to verse 72 of the Ahzâb chapter which says, "We do indeed offer the trust to the Heavens and the Earth and the Mountains, but they refuse to undertake it, being afraid thereof: But man undertook it; he was indeed unjust and foolish" (p. 679).

A Persian reader, given background knowledge as well as his/her religious beliefs, instantly realizes that the expression 'بار امانت refers to Qur'anic verses that are culture-bound The verses may cause some special cognitive effect due to the mood of the reader, and may be strange or unfamiliar to an English reader. In other words, the translated expression 'load of deposit' will not have the same effect on the TL reader as it as on the SL reader. However, Clarke, 
by rendering word for word, did not convey the connotations as well as the alluding part. He just had made minimal changes through the translation. Keep this verse in obscurity and it would not convey such layers of meaning in the target language and likely would remain nonsense or unfamiliar for target text readers. Hence, the translator used the literal translation for the translation of this allusion.

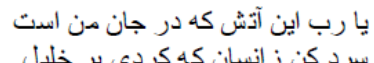

English translation:

O Lord! This fire (of separation) that within my soul is, make cool (to give me escape from separation; and to cause to attain union with Thee) in that way that to Khalil Thou didst (Clarke, 2005, p. 313).

This couplet alludes to the verses 68 and 69 of surah Anbiyâ. Abraham (ابراهي) is recognized in Islam as a prophet of God. In Muslim belief, Abraham fulfilled all the commandments and trials with which God tried him over his lifetime. As a result of his unwavering faith in God, Abraham was promised by God to be a leader to all the nations of the world. But Abraham's people ignored Abraham's warning and retaliated by throwing him into a fire and exclaiming "protect your gods". Although the natural nature of fire is one of intense heat, God commanded the flame to be cool and peaceful for Abraham. He, as a result, remained unhurt both physically and spiritually, having survived the fire of persecution (Estelami, 2009, p. 795-6).

According to the above, in the case of the prophet's name, the translator had merely retained the name without any guidance and kept it completely obscure for the target text reader. But some lexical and orthographical changes are really needed to reduce this obscurity by changing 'Khalil' into 'Abraham' to make it familiar for the target text readers. In the case of the whole couplet and the allusion within it, the translator used the literal translation with adding some minimum changes and unnecessary explanations.

\section{RESUlTS}

To make a summary of the results, there were altogether 50 Couplet identified in Hafez's Divan that the researcher tried to analyze the Qur'anic allusions within them based on Leppihalme's strategies respectively. The most common strategies used by the translators for the translation of these allusions are shown by the following figures.

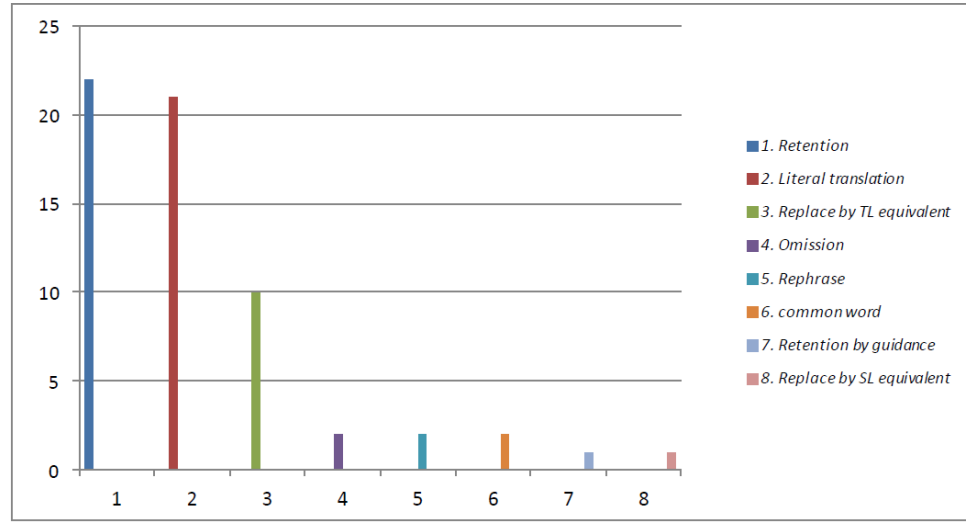

Figure 1: The frequency of strategies used by Clarke for rendering Qur'anic allusions in Hafez's poetry

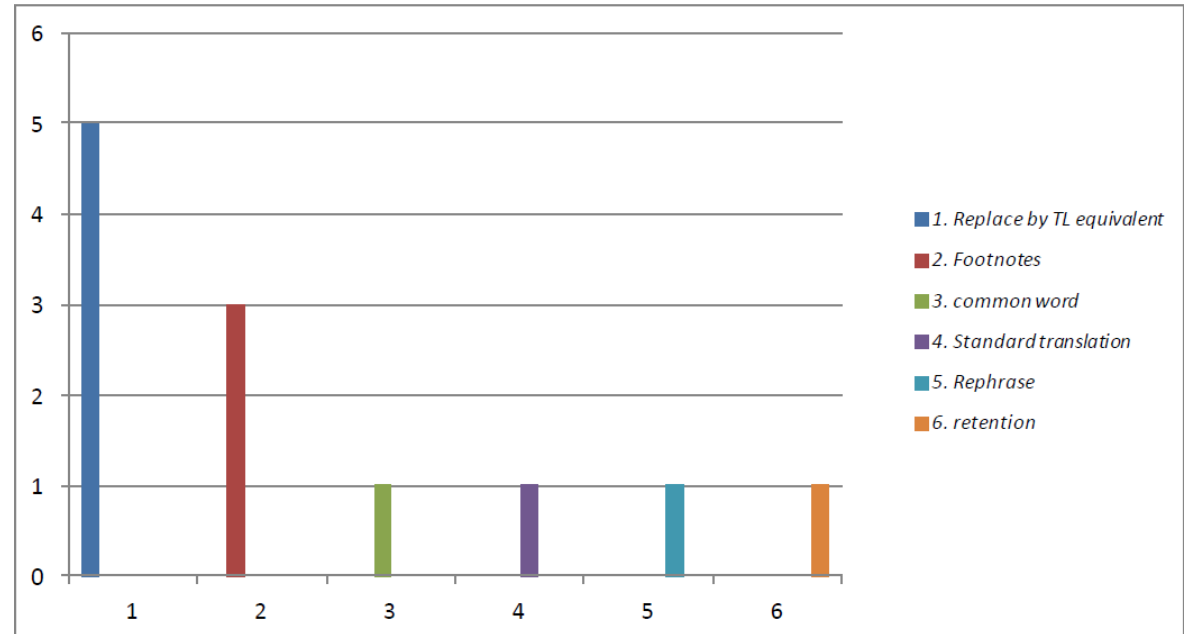

Figure 2: The frequecy of strategies used by Ordoubadian in translating Qur'anic allusions in Hafez's poetry 


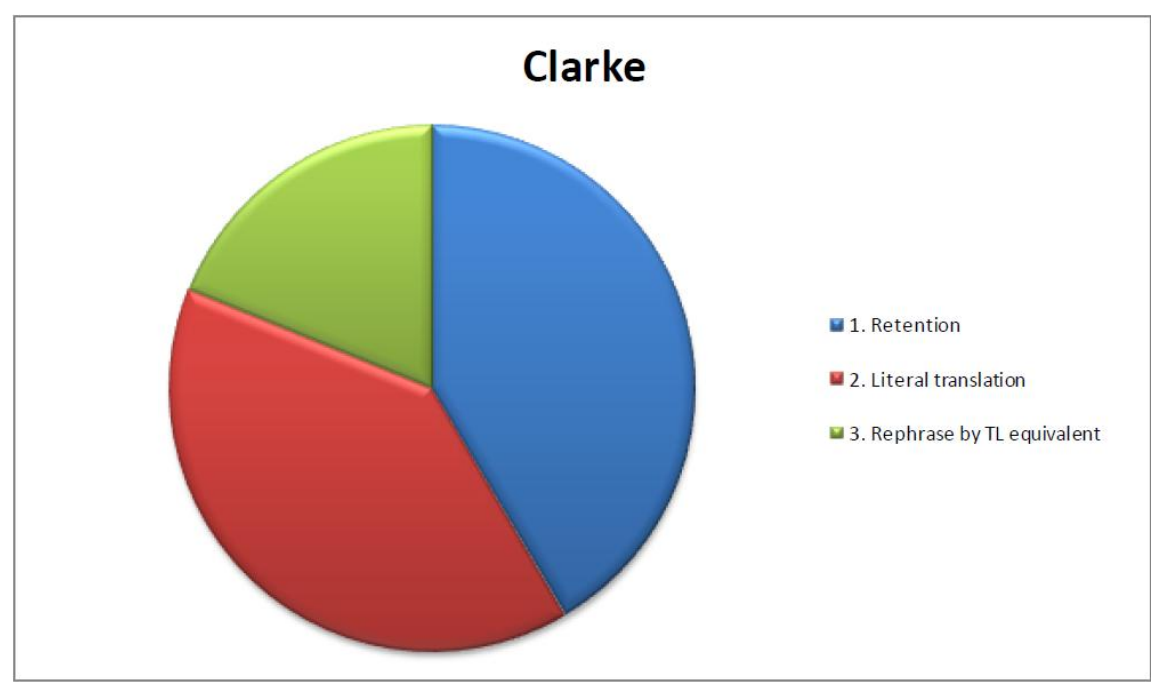

Figure 3: The percentage of three main strategies for translating Qur'anic allusions in Hafez's poetry

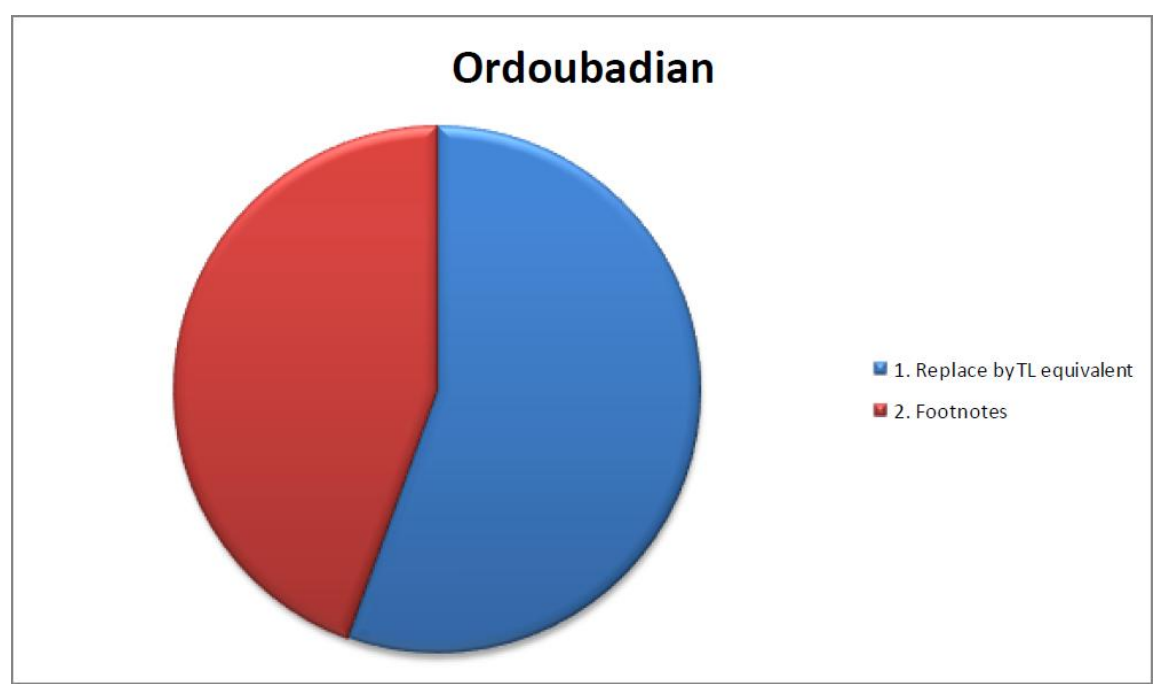

Figure 4: The percentage of two main strategies for translating Qur'anic allusions in Hafez's poetry

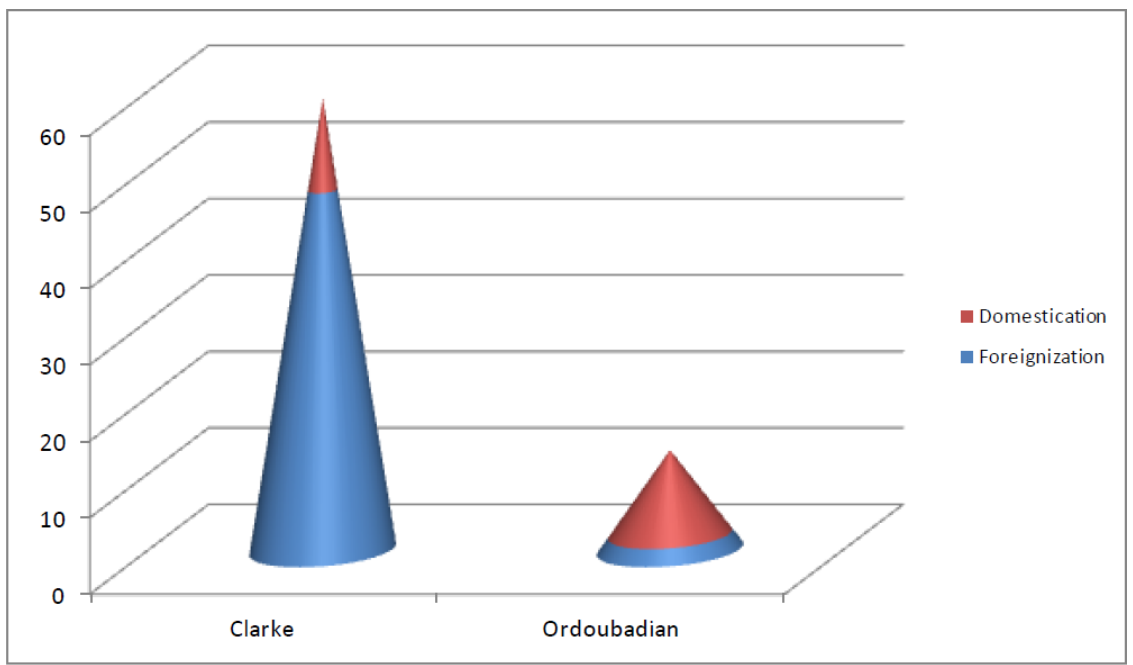

Figure 5: The ratio of domesticating and foreignizing strategies in both translations

Results of the Survey:

Following the overall purpose of the study in this thesis, this survey has been conducted using an online questionnaire administered to a group of native speakers of English. They were asked to read the intended ghazal of Hafez on their own pace and to underline any words they were not completely familiar with and make suggestions about its translation.

The survey results presented in this thesis are shown in the following figure. 


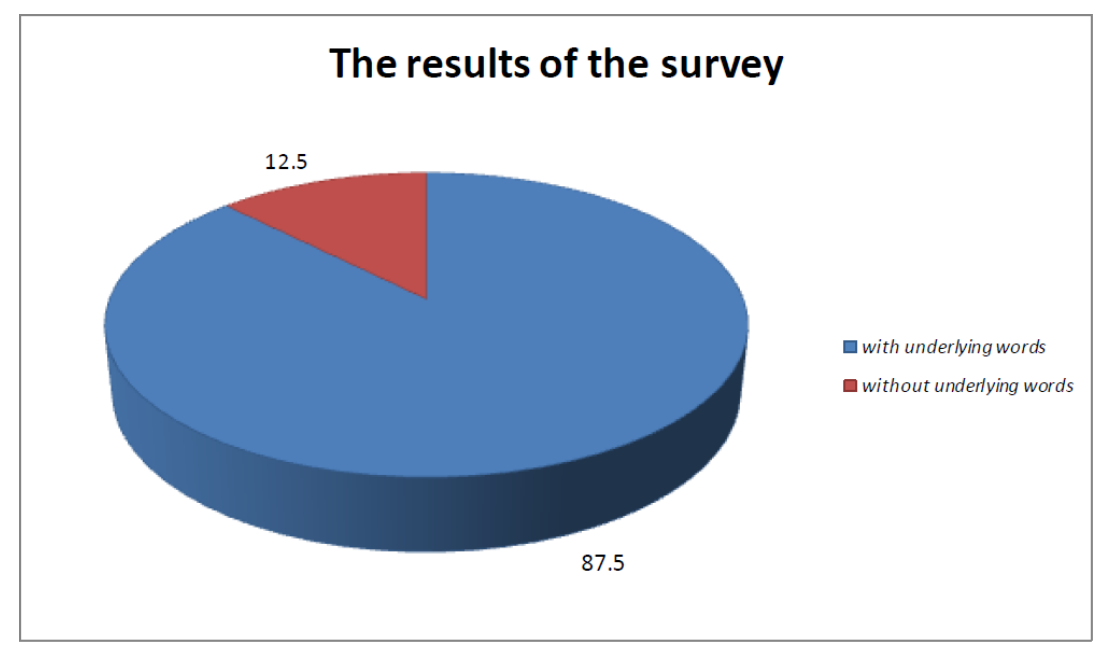

Figure 6: The ratio of answers consisted of underlying words to those without underlying words

The results approximately show that $87.5 \%$ of answers consisted of underlying words; showing that the allusion has been spotted but that its source was unknown. And full identification was given only in $12.5 \%$ of the answer.

\section{CONCLUSION}

The present study attempted to detect the treatment of culture-specific items and the strategies applied for their rendering through translation within a descriptive framework. In the beginning we embarked on an analysis of translation of Qur'anic allusions in Hafez's poems from Persian into English. For this purpose we presented each couplet with its English translation in front of it and then compared them at both textual and cultural level with their English translations. Although this paper cannot be considered as highly comprehensive, attempts were made to provide as many examples as possible.

It is obvious that most of the proper nouns and phrases have allusions which refer to other texts. It seems necessary for an acceptable translation to produce the same or at least similar effects on the TT readers as those created by the original work on its readers. But most translators do not appear to be successful in their challenging tasks of efficiently rendering the allusions when they sacrifice, or at least minimize, the effect of allusions in favour of preserving graphical or lexical forms of source language allusions. In other words, a competent translator is well-advised not to deprive the TL reader of enjoying, or even recognizing, the allusions either in the name of fidelity or brevity. Hence, the translator carefully searches for strategies to cope with these problems. Consequently, the translator's choice of strategy for the translation of allusive elements may subtly result in preventing the TT readers from spotting and enjoying allusions and in failure to transfer the connotation the original author intended to evoke in his/her readers. Beyond a shadow of doubt, the choice of strategy is related to the translator's fidelity or lack of fidelity to the ST author. The findings of this study suggested that Clark's translations can be more faithful to the ST author when he uses "retention" and "literal translation" as the most frequent strategies for rendering Qur'anic allusions. Consequently studying the small portion of Ordoubadian's translations showed that the most frequent strategies used by him in rendering such Qur'anic concepts were "replacement by a target language equivalent" and "use of footnotes and endnotes".

However, the researcher of the present study is of the opinion that Clarke failed to elaborate at length upon the allusions as well as the stories behind references. In other words, he could employ more extensive translation strategies so that the target text readers might understand the implied references. One must mention that native speakers and readers who live in the author's linguistic and cultural community may fail to recognize the allusive nature of an element in a text. This difficulty is intensified when the receptor is not the native speaker of the source language and is from a culture different from that of the source one and; consequently, has more limitations in accessing the source of allusions.

However, it is necessary not only for competent readers (poets, authors) in SL but also for translators to grasp these allusions so that they can convey the connotations to competent TL readers.

Since culture-bound elements as their name infers are limited to the culture in which they occur, at the first phase it might be difficult for readers outside that culture to grasp and understand cultural elements easily. Following the same line, background knowledge of the reader plays a major role in perceiving a text properly, for examples in our discussed poems; allusions such as "Yusuf, Khalil, Masiha, Ka'ba, and Qarun" are familiar for SL readers who have some knowledge or information about them. Perhaps they have heard or experienced them in their own culture. Hence they could easily digest and accept those concepts in their own culture without any negative mental struggle and the concepts will have their special effects on the SL readers. Thus the readers or translators use their background knowledge or information to interpret different texts and recreate writer's meaning. The fact is that inferring the writers' purpose, intended meaning to more extent will depend on the readers' or target text translators' background knowledge. 
Consequently, many interpretations will exist for just one discourse, especially for literary texts. Since this background knowledge is not shared by the TL readers reading the same poem, the translator does not care about establishing proper TL equivalents. As a result, target text readers fail to understand or infer the implied meaning of cultural elements, and the same effect on the SL would be diminished in the target language and culture. Therefore, in the case of highly culture-bound elements that are liable to different interpretations, the TL readers' background knowledge or information makes the process of understanding and inferring quite difficult and different for them in comparison to those who are lacking because they belong to a different culture and society.

First, it was revealed that strategies adopted by various translators are generally focused on domesticating a term or preserving its local color and cultural strangeness. Consequently, any strategy adopted by the translator is to pursue one of these two points, which vary among translators. Thus, in either case, the loss of some part of the meaning or its effect, in terms of the source culture or target culture may occur. Second, it was discovered that not only are translation strategies different among various translators, but also every translator applies a range of them through his/her work. It is not just a matter of taste or style, but also a matter of context, that shapes the very decision making process of the translator, when he/she deals with cultural elements. Therefore, we could decide that no cultural element can be studied irrespective of its context. Following the discussions, it was revealed that the overall strategy used by Clarke was a foreignization strategy, driven by trying to retain something of the foreignness of the original. However, in the case of Ordoubadian, there was an attempt to choose a translation strategy in which the transparent and fluent style was adopted in order to minimize the strangeness of the foreign text for the target language readers. It tried to act as a domesticated translation.

\section{REFERENCES}

[1] Albakry, M. (2004). Linguistic and cultural issues in literary translation. Translation Journal 8(3). Retrieved from http://translationjournal.net/journal/29liter.htm (accessed 29/5/2012).

[2] Arberry, J. (1974). Fifty Poems of Hafiz. London: Cambridge University Press.

[3] Asad, T. (2009). The concept of cultural translation in British social anthropology. In Mona Baker (Ed.) Critical Readings in Translation Studies. London \& New York: Routledge.

[4] Brislin, R.W. (Ed.) (1976). Translation: Applications and Research. New York: Gardner Press.

[5] Clarke, H.W., Sasani, H. (Eds.) (2005). The Divan of Hafiz: English-Persian. Tehran: Aban Books ( $1^{\text {st }}$ ed.).

[6] Connolly, D. (1998). Poetry translation. In Mona Baker (Ed.), Routledge Encyclopedia of Translation Studies (pp.170-176). London \& New York: Routledge.

[7] Cvilikaite, J. (2006). Lexical Gaps: Resolution by Functionally Complete Units of Translation. Retrieved from http://www.scribd.com/doc/88730528/Lexical-Gaps-Ro-Eng (accessed 5/8/2012)

[8] Darwish, A. (2010). Elements of Translation. Melbourne: Writescope.

[9] Eslaminejad, A. (1996). The Effect of Qur'an and Hadiths in Hafez's poetry. Kashan: Morsal Publication.

[10] Estelami, M. (2009). Dars-e-Hafez (Understanding Hafez). Vol. (1\&2). Tehran: Sokhan Publication.

[11] Harvey, M. (2003). A beginner's course in legal translation: the case of culture-bound terms. http://www.tradulex.org/Actes2000/harvey.pdf (accessed 23/9/2012).

[12] Hassan, B. A. (2011). Literary Translation: Aspects of Pragmatic Meaning. Newcastle upon Tyne: Cambridge Scholars Publishing.

[13] Hornby, A. S. (2004). Oxford Advanced Learner's Dictionary. Oxford University Press.

[14] House, J. (1997). Translation Quality Assessment: A Model Revisited. Tübingen: Narr.

[15] Jääskeläinen, R. (1999). Tapping the process: An explorative study of cognitive and effective factors involved in translating. Joensuu: University of Joensuu Publications.

[16] Jakobson, R. (1959/2004). On linguistic aspects of translation. In Lawrence Venuti (Ed.), The Translation Studies Reader (2004) (pp.138-143). London: Routledge.

[17] Khorramshahi, B. (2001). Hafiz-Nameh (A Selective Commentary of Hafiz Ghazals). Vol. (1) (2) Tehran: Soroush Publication.

[18] Larson, M. L. (1984). Meaning-Based Translation: A Guide to Cross-Language Equivalence. Lanham \& New York: University Press of America.

[19] Leppihalme, R. (1997). Culture bumps: An empirical approach to the translation of allusions. Topics in Translation, 10. Clevedon: Multilingual Matters.

[20] Lörscher, W. (1991). Translation Performance, Translation Process and Translation Strategies: A Psycholinguistic Investigation. Tübingen: Gunter Narr.

[21] Miremadi, S.A. (2005). Theoretical Foundations and Principles of Translation. Tehran: SAMT.

[22] Mohaghegh, A. (2011), Clarke's (1891) translation of Ghazal 167 by Hafez: A text-based approach in criticism at linguistic level based on Reiss' (1971) model. International Social Research, 4(18). http://www.sosyalarastirmalar.com/cilt4/sayi18_pdf/1_dil_edebiyat/mohaghegh_ameneh.pdf (accessed 2/9/2012).

[23] Nabokov, V. (2004). Problems of translation: Onegin in English. In Lawrence Venuti (Ed.) (2004), The Translation Studies Reader, $2^{\text {nd }}$ ed., pp.115-127. New York: Routledge.

[24] Newmark, P. (1988). Approaches to Translation. Hertfordshire: Prentice Hall.

[25] Nida, E. A., \& Taber, C. R. (1974). The Theory and Practice of Translation. Leiden: E. J. Brill.

[26] Nord, C. (1991). Text Analysis in Translation. Amsterdam: Rodopi.

[27] Ordudari, M. (2007), Translation procedures, strategies and methods. Translation Journal 11(3). Retrieved from http://translationjournal.net/journal/41 culture.htm

[28] Ordoubadian, R. (2006). The Poems of Hafez. Bethesda, MD: IBEX Publishers. 
[29] Oswalt, W. H. (1970). Understanding Our Culture: An Anthropological View. New York: Holt, Rinehart \& Winston.

[30] Snell-Hornby, M. (1988). Translation Studies: An Integrated Approach. Amsterdam: John Benjamins.

[31] Wilss, W. (1983). Translation Strategies, Translation Method and Translation Technique: Towards a Clarification of Three Translational Concepts. Revue de Phonétique Appliquée 66-67-68, pp. 143-52.

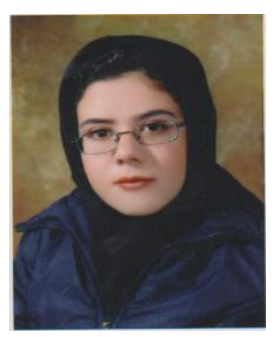

Masoumeh Rahimkhani was born in Shabestar, Iran, in 1987. She lives in Shabestar. She is an M.A. candidate of Translation Studies at Science and Research University of Tabriz, Iran. She received her B.A. in the field from Azad University of Tabriz, Iran in 2009. Her main areas of interest include literary translation and cultural aspects in translation.

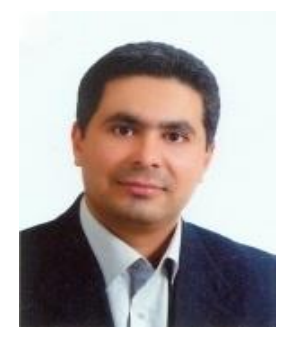

Bahloul Salmani was born in Tabriz, Iran, 1974. He holds a PH.D in Translation Studies. He is currently an Assistant Professor in the Department of English Language and Literature of Azarbaijan Shahid Madani University. His main area of interest includes cultural semiotics. 